\title{
BMJ Global Health COVID-19 travel restrictions and the International Health Regulations (2005)
}

\author{
Barbara von Tigerstrom (D) ,' Kumanan Wilson (D) ${ }^{2,3}$
}

To cite: von Tigerstrom B, Wilson K. COVID-19

travel restrictions and the International Health Regulations (2005). BMJ Global Health 2020;5:e002629. doi:10.1136/ bmjgh-2020-002629

Handling editor Seye Abimbola

Received 10 April 2020

Revised 4 May 2020

Accepted 5 May 2020
Check for updates

(C) Author(s) (or their employer(s)) 2020. Re-use permitted under CC BY-NC. No commercial re-use. See rights and permissions. Published by BMJ.

${ }^{1}$ College of Law, University of Saskatchewan, Saskatoon, Saskatchewan, Canada ${ }^{2}$ Bruyère Research Institute, Ottawa, Ontario, Canada ${ }^{3}$ Clinical Epidemiology Program, Ottawa Hospital Research Institute, Ottawa, Ontario, Canada

\section{Correspondence to} Dr Barbara von Tigerstrom; barbara.vontigerstrom@usask. ca

\section{INTRODUCTION}

From the early stages of the COVID-19 pandemic, there have been concerns that states are violating their obligations under the International Health Regulations (2005) (IHR (2005) $)^{1}$ by imposing restrictions on international travel. ${ }^{2}{ }^{3}$ These concerns are justified, but in this unprecedented situation, there are few clear answers. What is evident from the unfolding of events is that either the WHO's guidance on travel was wrong and had a serious negative impact on the spread of disease, or states' actions to prevent the spread of disease through travel restrictions have unnecessarily had a serious negative impact on the global economy. We expect the answer is somewhere in between, but it appears that the IHR (2005) framework to prevent unnecessary interference with international travel and trade is not succeeding as intended.

\section{TIMELINE OF COVID-19 AND TRAVEL-RELATED DECISIONS}

After reports of a novel coronavirus emerged in January, the WHO advised the usual precautions for travellers and consistently recommended against any travel or trade restrictions on China. ${ }^{4-6}$ The WHO DirectorGeneral issued Temporary Recommendations under the IHR (2005) after declaring a public health emergency of international concern (PHEIC) on 30 January, again not recommending travel or trade restrictions, although urging measures to prevent international spread as well as secondary transmission. ${ }^{7}$ Updated guidance in late February continued to recommend against restrictions, except perhaps in very limited circumstances. ${ }^{8}$ Most of this advice has been provided not in formal Temporary Recommendations but in other guidance documents, the legal status of which is somewhat unclear. ${ }^{9}$ The Temporary Recommendations issued on January 30 remained in place until the end of April, when the PHEIC

\section{Summary box}

Concerns that have been raised about states violating the International Health Regulations (2005) by imposing travel restrictions are valid, and some states have not complied with their obligations under those Regulations.

- Given the unprecedented situation and uncertainty about the best course of action, we should not assume that all travel restrictions violate international law, even though they were not recommended by the WHO.

- Some travel restrictions are more likely to be justified than others, depending on a number of factors, including how they are designed and local capacity to implement less restrictive measures.

- The WHO still has an important role to play in providing guidance to states as they modify or lift travel restrictions.

In order for the international framework to be more effective, the WHO should have more flexibility to make early travel recommendations and develop protocols to facilitate the reopening of borders.

declaration was continued and new recommendations were issued. ${ }^{10}$ The new Temporary Recommendations continued to recommend 'appropriate travel measures' such as entry and exit screening, and that states should 'review travel and trade measures based on regular risk assessments, transmission patterns at origin and destination, costbenefit analysis, evolution of the pandemic, and new knowledge of COVID-19'. ${ }^{10}$

Contrary to WHO guidance, a large number of states-by the end of March, almost every country in the world-implemented some type of mandatory restrictions on international travel. A handful of states imposed restrictions against China in January, and after the PHEIC declaration, many more followed suit. These measures include denial of entry based on nationality or travel history, suspension of air travel and visa restrictions, among others. As the outbreak spread, restrictions against other countries were added; by late March, many countries had closed their 
borders to most international travellers-a situation unprecedented at least in modern times. A month later, most of those restrictions remained in effect, despite a growing number of states beginning to lift some internal measures.

\section{IMPLICATIONS OF DECISIONS}

The IHR (2005) emerged from the International Sanitary Conventions, created in Europe during the 1800s to address exactly the kind of concerns that emerged with COVID-19, the excessive closing of borders in the face of cholera outbreaks. The aim of the IHR (2005) is to 'prevent, protect against, control and provide a public health response to the international spread of disease', while avoiding 'unnecessary interference with international traffic and trade'.

The WHO's hesitance to recommend any restrictions on international travel or trade may be understandable, given the available evidence on their impact, and a long history of such measures being taken with little or no scientific justification - with travel bans during the 20142016 Ebola virus outbreak being just one recent, notable example. ${ }^{11}{ }^{12}$ Nevertheless, not introducing potentially effective travel restrictions at the earliest stages is contrary to the goal of the IHR (2005) to prevent the spread of public health threats. Scientifically, the best opportunity to prevent the spread of disease is at the beginning of the epidemic curve. Taking a precautionary approach, the evidentiary threshold to act thus must be low, even recognising the negative economic consequences. One limitation of the IHR (2005) is that Temporary Recommendations are issued only once a PHEIC is declared, at which point it may already be too late for measures to be most effective. By the time WHO acknowledged, in late February, that restrictions on travel might have some limited value, ${ }^{8}$ the window of opportunity to prevent a pandemic had long been closed.

Conversely, if there was no evidence that travel restrictions were of value, as stated by the WHO, the imposition of travel restrictions in response to COVID-19, contrary to $\mathrm{WHO}$ advice, is problematic given their enormous economic consequences. Given the uncertainty as to which is the better course of action, however, it is difficult to conclude that all of the current restrictions violate states' international obligations.

One clear issue is states' non-compliance with the IHR (2005) requirement to notify WHO of the rationale and basis for measures that constitute a 'significant interference' with international traffic, defined as the refusal or delay of entry or exit for more than 24 hours. ${ }^{1}$ Many such measures appear not to have been reported to the WHO. ${ }^{13}{ }^{14}$ In the current environment, transparency of states' measures relies less on these official reportsmost travel restrictions have been widely reported by the media and other sources. Nevertheless, failure to report is a violation of WHO members' explicit legal obligations and hampers WHO engagement with governments that are taking these measures.

The glaring mismatch between WHO recommendations and the widespread use of travel restrictions also raises red flags, but not all restrictions violate the IHR (2005) just because they were not recommended by WHO. The IHR (2005) do not say that states must always follow WHO recommendations. ${ }^{1}$ However, states did commit to basing their decisions on available information from the WHO or other organisations, and 'any available specific guidance or advice from WHO'. They are also required to base their decisions on scientific principles and available scientific evidence or information, and to use measures that are not more restrictive than reasonably available alternatives that would provide an appropriate level of protection. ${ }^{1}$ This is where we need to evaluate states' decisions more carefully, given the unprecedented nature of the current pandemic. It may be too early to draw definitive conclusions about the scientific justification and proportionality of the wide range of measures that have been used, and a full analysis will be an important component of the review of the pandemic response. At this point, we can identify factors that will make some measures easier to justify than others.

Imposing restrictions based on nationality (rather than travel history) is always suspect, given the weak correlation between nationality and exposure to the virus. Excluding people based on the passport they carry also carries a greater risk of contributing to stigma and discrimination, and the IHR (2005) and other laws require states to respect human rights and avoid discrimination. Any type of restriction that targets specific countries becomes increasingly difficult to justify once other countries begin reporting similar or larger numbers of cases. Most, but not all, states replaced these targeted measures with broad-based restrictions as the pandemic spread. Other actions, such as blocking access to ports, must also be scrutinised closely. In this case and others, whether a ban on access or entry can be justified as the least restrictive measure available may depend on local capacity and other factors. Official statements and other sources may also give some indication as to whether states are complying with their obligations to take relevant factors (eg, scientific evidence and WHO advice) into account when making decisions about restricting international traffic.

When it comes to the scientific basis for measures, many have argued that travel restrictions are not effective in preventing the spread of disease, because at best, they delay the introduction of a novel pathogen rather than preventing it. ${ }^{812}{ }^{14}$ However, as even the WHO has acknowledged, ${ }^{8}$ there may be situations in which this delay could have value, particularly for a small low and middle-income country with very limited capacity, for example. The impact of restrictions on essential goods and services, another common concern, ${ }^{2810}$ may depend on how measures are designed and implemented. 
In the latest phase of the pandemic, with about 200 states and territories reporting confirmed cases by the end of March (at least 160 of those with local transmission), ${ }^{15}$ restrictions on international traffic make little sense for most countries if we assume the intent is to keep the virus from entering the local population. However, since movement within each country is also strictly limited in many countries, travel restrictions could be seen as part of a larger strategy to minimise movement and contact. Indeed, the updated COVID-19 strategy document released by the WHO in mid-April refers to 'appropriate and proportionate restrictions on non-essential domestic and international travel' as one way to suppress community transmission. ${ }^{16}$

The key questions are now how long the current measures should stay in place, and when and how they should be modified or removed. Much attention is quite rightly focused on the impact of internal measures on national economies and populations, especially the most vulnerable. Governments have many difficult choices to make, including when and how borders should begin to reopen and restrictions on international travel be relaxed or removed-before or after limits on domestic travel or other local measures, selectively or for all international travel, and so on. These decisions are further complicated by significant differences between (and sometimes within) states in terms of numbers of cases and the timing of changes to internal restrictions.

Under the IHR (2005), states must review their measures within 3 months, again taking into account scientific principles and evidence and WHO guidance, and aiming for the least restrictive measures that will provide an adequate level of protection. As states balance the risks of relaxing restrictions prematurely against the social and economic cost of continuing them, there is limited evidence available to guide them. It seems unlikely that states will suddenly begin to follow WHO recommendations in making these choices, but information, guidance and practical support from the WHO could still be useful. At its April 30 meeting, the Emergency Committee's advice to WHO included that it develop 'strategic guidance with partners for the gradual return to normal operations of passenger travel' and update recommendations on appropriate travel measures. ${ }^{10}$

\section{RECOMMENDATIONS}

For the IHR (2005) to be effective regarding regulation of international travel and trade in the future, several changes need to occur. First, the WHO needs to be empowered to take early action to limit travel. Arguably, early restriction of travel to or from China could have substantially limited the global spread of the disease. The WHO would need to be able to bring in travel recommendations well before the declaration of a PHEIC, a point at which the best chance of preventing spread of the disease would have passed. A graded alert or emergency declaration approach as has been suggested by others would be an important step towards achieving this objective. ${ }^{9}{ }^{17}$ Given that it may be challenging for the WHO to recommend restrictions in specific instances, it could also provide more detailed general recommendations on best practices and principles to guide states' decisions in these situations. Further analysis of the various restrictions that have been implemented over the course of the COVID-19 pandemic and their effects could inform such recommendations.

Second, a fund needs to exist to support countries, particularly low and middle-income countries, that report disease outbreaks early and suffer economic consequences. This could be created by the WHO and its member states in conjunction with the World Bank and other relevant agencies. It would supplement other efforts to promote solidarity and support more vulnerable members of the global community, such as initiatives to collaborate in developing and sharing vaccines and treatments. ${ }^{18}$ These efforts are essential to the reciprocity underlying the IHR (2005): that member states will comply with their capacity and reporting obligations and in return, are entitled to expect to be treated fairly and supported when they are affected by outbreaks and the associated economic consequences.

Third, WHO could coordinate or facilitate strategies to effectively reopen borders. In this case, this could eventually involve establishing some standard for immunity, be it serological or immunisation, analogous to the Yellow Fever International Certificate of Vaccination, which is recognised under the IHR (2005) as one that member states can require as a condition of entry. ${ }^{1}$ If this type of certificate for severe acute respiratory syndrome coronavirus 2 immunity becomes a feasible option, the WHO would be best placed to create this standard and incorporate it into the IHR (2005).

\section{CONCLUSION}

Early concerns that states are violating the IHR (2005) by implementing travel restrictions contrary to WHO advice have given way to a more complex and nuanced picture. Some states appear not to have complied with their obligations to report additional measures, to base measures on scientific principles and evidence and to use the least restrictive measures available. For some measures, however, it is less clear that they violate IHR (2005) obligations even if they were not recommended by the WHO, particularly if restrictions on international traffic are implemented as part of a larger strategy to limit movement and contact. The WHO's ability to recommend restrictions at an early stage, when they would have been most useful, was likely hampered by a number of factors, including a lack of flexibility in the IHR (2005) framework. Now faced with the reality of widespread border closures, the WHO still has a useful role to play in informing and supporting the difficult decisions that states need to make in the months ahead. Going forward, changes are needed to make the IHR (2005) a more 
effective framework, including empowering the WHO to take early action, a fund to support affected states and WHO-coordinated strategies to reopen borders.

Acknowledgements Justin Okerman (University of Saskatchewan College of Law) provided assistance with research for this article.

Contributors BVT and KW conceived and designed the work and contributed to the analysis. BvT produced the first draft of the article. BvT and KW added to and revised the article and approved the final version.

Funding The research was supported by a grant to KW from the Canadian Institutes of Health Research (Canadian 2019 Novel Coronavirus (2019-nCoV) Rapid Research, grant number NFRF-2019-00013).

Competing interests KW has acted as a consultant for the WHO on two occasions.

Patient consent for publication Not required.

Provenance and peer review Not commissioned; externally peer reviewed.

Data availability statement There are no data in this work.

Open access This is an open access article distributed in accordance with the Creative Commons Attribution Non Commercial (CC BY-NC 4.0) license, which permits others to distribute, remix, adapt, build upon this work non-commercially, and license their derivative works on different terms, provided the original work is properly cited, appropriate credit is given, any changes made indicated, and the use is non-commercial. See: http://creativecommons.org/licenses/by-nc/4.0/.

\section{ORCID iDs}

Barbara von Tigerstrom http://orcid.org/0000-0002-7145-6086

Kumanan Wilson http://orcid.org/0000-0002-1741-7705

\section{REFERENCES}

1 World Health Organization. International health regulations (2005). 2nd ed. Geneva: World Health Organization, 2008.

2 Habibi R, Burci GL, de Campos TC, et al. Do not violate the International Health Regulations during the COVID-19 outbreak. Lancet 2020;395:664-6.

3 Meier BM, Habibi R, Yang YT. Travel restrictions violate international law. Science 2020;367:1436.

4 World Health Organization. WHO advice for international travel and trade in relation to the outbreak of pneumonia caused by a new coronavirus in China. Available: https://www.who.int/news-room/ articles-detail/who-advice-for-international-travel-and-tradein-relation-to-the-outbreak-of-pneumonia-caused-by-a-newcoronavirus-in-china/ [Accessed 4 May 2020].

5 World Health Organization. Updated WHO advice for international traffic in relation to the outbreak of the novel coronavirus 2019-nCov. Available: https://www.who.int/news-room/articles-detail/updatedwho-advice-for-international-traffic-in-relation-to-the-outbreak-ofthe-novel-coronavirus-2019-ncov-24-jan/ [Accessed 4 May 2020]

6 World Health Organization. Updated WHO advice for international traffic in relation to the outbreak of the novel coronavirus 2019-nCov.
Available: https://www.who.int/news-room/articles-detail/updatedwho-advice-for-international-traffic-in-relation-to-the-outbreak-ofthe-novel-coronavirus-2019-ncov [Accessed 4 May 2020].

7 World Health Organization. Statement on the second meeting of the International health regulations (2005) Emergency Committee regarding the outbreak of novel coronavirus (2019-nCoV). Available: https://www.who.int/news-room/detail/30-01-2020-statementon-the-second-meeting-of-the-international-health-regulations-( 2005)-emergency-committee-regarding-the-outbreak-of-novelcoronavirus-(2019-ncov) [Accessed 4 May 2020].

8 World Health Organization. Updated WHO recommendations for international traffic in relation to COVID-19 outbreak. Available: https://www.who.int/news-room/articles-detail/updated-whorecommendations-for-international-traffic-in-relation-to-covid-19outbreak [Accessed 4 May 2020].

9 Burci GL. The outbreak of COVID-19 coronavirus: are the International Health Regulations fit for purpose? 2020. Available: https://www.ejiltalk.org/the-outbreak-of-covid-19-coronavirus-arethe-international-health-regulations-fit-for-purpose/

10 World Health Organization. Statement on the third meeting of the International health regulations (2005) Emergency Committee regarding the outbreak of coronavirus disease (COVID-19). Available: https://www.who.int/news-room/detail/01-05-2020-statement-onthe-third-meeting-of-the-international-health-regulations-(2005)emergency-committee-regarding-the-outbreak-of-coronavirusdisease-(covid-19) [Accessed 4 May 2020].

11 Pattani R. Unsanctioned travel restrictions related to Ebola unravel the global social contract. CMAJ 2015;187:166-7.

12 Tejpar ALI, Hoffman SJ. Canada's Violation of International Law during the 2014-16 Ebola Outbreak. Can Yearb Int Law 2017;54:366-83.

13 World Health Organization. Novel coronavirus (2019-nCoV) situation report - 18. Available: https://www.who.int/docs/default-source/ coronaviruse/situation-reports/20200207-sitrep-18-ncov.pdf?sfvrsn= fa644293_2 [Accessed 4 May 2020].

14 World Health Organization. Novel coronavirus (2019-nCoV) situation report - 39. Available: https://www.who.int/docs/default-source/ coronaviruse/situation-reports/20200228-sitrep-39-covid-19.pdf? sfvrsn=5bbf3e7d_4 [Accessed 4 May 2020].

15 World Health Organization. Novel coronavirus (2019-nCoV) situation report - 71. Available: https://www.who.int/docs/default-source/ coronaviruse/situation-reports/20200331-sitrep-71-covid-19.pdf? sfvrsn=4360e92b_8 [Accessed 4 May 2020].

16 World Health Organization. COVID-19 strategy update. Available: https://www.who.int/docs/default-source/coronaviruse/covidstrategy-update-14april2020.pdf?sfvrsn=29da3ba0_19 [Accessed 4 May 2020].

17 Kelland K, Nebehay S. WHO officials rethink epidemic messaging amid pandemic debate, 2020. Available: https://www.reuters. com/article/us-health-coronavirus-who-messaging-insi/whoofficials-rethink-epidemic-messaging-amid-pandemic-debateidUSKBN2101AY [Accessed 4 May 2020].

18 World Health Organization. Commitment and call to action: global collaboration to accelerate new COVID-19 health technologies, 2020. Available: https://www.who.int/news-room/detail/24-042020-commitment-and-call-to-action-global-collaboration-toaccelerate-new-covid-19-health-technologies [Accessed 4 May 2020]. 